\title{
Thoracic Wounds by Firearm at the University Hospital Yalgado Ouedraogo (YO)
}

\author{
Edgar Ouangré*, Maurice Zida, Moussa Bazongo, Elie Yamba Sawadogo, Aristide Sam, \\ Rock Kafando, Nayi Zongo, Si Simon Traoré \\ Department of General and Digestive Surgery, University Hospital-Yalgado Ouédraogo, Ouagadougou, Burkina Faso \\ Email: *ouangredgar@yahoo.fr
}

How to cite this paper: Ouangré, E., Zida, M., Bazongo, M., Sawadogo, E.Y., Sam, A., Kafando, R., Zongo, N. and Traoré, S.S. (2017) Thoracic Wounds by Firearm at the University Hospital Yalgado Ouedraogo (YO). Open Journal of Thoracic Surgery, 7 , 23-28.

https://doi.org/10.4236/ojts.2017.72004

Received: May 22, 2017

Accepted: June 27, 2017

Published: June 30, 2017

Copyright $\odot 2017$ by authors and Scientific Research Publishing Inc. This work is licensed under the Creative Commons Attribution International License (CC BY 4.0).

http://creativecommons.org/licenses/by/4.0/

\begin{abstract}
Introduction: Thoracic wounds by firearms are frequent and severe. They may involve the patient's prognosis. Objective: To study the epidemiological, clinical, paraclinical, therapeutic and evolutionary aspects of the thoracic wounds by firearms. Material and method: This was a cross-sectional, descriptive study of all patients over the age of 15 who consulted in the university hospital-YO in the department of general and digestive surgery over a period of 5 years. Results: We collected 50 cases of thoracic wounds by firearms on 183 thoracic wounds with a prevalence of $27.3 \%$. There were 48 men (96\%). The average age was 30 years. The patients came from urban areas in $66 \%$ of cases; the informal sector accounted for $44 \%$ of the cases. The pistol was the most involved firearm (46.9\%). The consultation period was less than 6 hours in $78 \%$ of patients. An unstable hemodynamic state was found in $42 \%(n=21)$. A fluid and mixed pleural effusion syndrome was found in $46 \%$ and $26 \%$ of patients, respectively. Associated lesions were diaphragm involvement, and lesions of intra-abdominal hollow organs. Thoracic drainage was performed in 24 patients (48\%) and was associated with a laparotomy in 8 patients. The average hospital stay was 7.5 days. Mortality was $14 \%$. Conclusion: the thoracic wounds by firearms are frequent in civilian practice. The thoracic CT allows mapping of the lesions and thoracic drainage constitutes the essential part of surgical treatment. The fight against the proliferation of weapons deserves to be promoted.
\end{abstract}

\section{Keywords}

Wounds, Thorax, Firearm, Drainage, Burkina Faso

\section{Introduction}

The thoracic wounds by firearm are relatively frequent trauma in surgical settings [1]. Adegboye et al. in Nigeria had recovered in civilian practice $61 \%$ of 
thoracic injuries among hospitalized patients for gun trauma [2]. However, Debien and Lenoir in France have noted a 19\% prevalence of chest trauma [3]. In war or armed conflict pathology, the thoracic involvement varies from $3 \%$ to $10 \%$ of all lesions [4] [5]. These are serious lesions and occur most often in a polytrauma context which can be life-threatening [1]. These thoracic wounds present a challenge of the lesional diagnosis [1]. Indeed since 2011, Burkina Faso has gone through a long period of political instability marked by mutinies, a popular insurrection and a military coup. During these periods of crisis, we noticed an increase in the number of victims of firearm trauma, including a significant proportion of thoracic wounds. The aim of this study was to describe the epidemiological, diagnostic, therapeutic and prognostic aspects of thoracic wounds by firearm at the university hospital Yalgado Ouédraogo of Burkina Faso.

\section{Patients and Methods}

We carried out a descriptive cross-sectional study over 5 years (January 2011December 2015) in the department of general and digestive surgery of the university hospital-YO of Ouagadougou. The patients admitted during this period constituted our study population. Included in our study, the patients aged at least 15 years admitted to the visceral emergencies unit and in whom the diagnosis of a gunshot wound was placed on the basis of clinical, paraclinical and per-operative. Patients under 15 years of age and all thoracic wounds of other origins (traffic accident, knife) were not included in our study. The variables studied were age, sex, occupation, residence, circumstances of occurrence, clinical and paraclinical signs, data on treatment and evolution.

\section{Results}

In 5 years we have collected 183 thoracic wounds, 50 of which by firearm with a prevalence of $27.32 \%$. The average age of patients was 30 years, with extremes of 19 and 60 years. There were 48 men and 2 women. The patients came from an urban and a rural environment in 66 and $34 \%$ respectively. Several socio-professional statuses were found. They have been represented in Table 1. Thirty-nine (78\%) patients were admitted to surgical emergencies in less than 6 hours. This delay was greater than 24 hours in $10 \%$ of cases. The circumstances

Table 1. Summary of socio-professional status of patients.

\begin{tabular}{ccc}
\hline Socio-professional categories & Number $(n=50)$ & Frequency (\%) \\
\hline State or private agent & 17 & 34 \\
Informal sector officer & 22 & 44 \\
Household & 2 & 4 \\
Cultivator/breeder & 4 & 8 \\
Students & 5 & 10 \\
Total & $\mathbf{5 0}$ & $\mathbf{1 0 0}$ \\
\hline
\end{tabular}


of the thoracic wound were armed assault in $60 \%$, street protests in $20 \%$, hunting accident (2\%) or accident of manipulation (4\%) and suicide attempts in $4 \%$. The nature of the weapon used was specified in 49 patients. It was a pistol in $46.9 \%$, a kalashnikov in $28.5 \%$; a shotgun in $20.4 \%$ and an explosive in $4.1 \%$. Clinically, $88 \%$ of patients had a Glasgow score of 15 . Consciousness was obsessed in 6 patients with a Glasgow score between 8 and 12. An unstable hemodynamic condition with a blood pressure lower than $80 / 60 \mathrm{mmHg}$ was noted In 21 patients (42\%). Thoracic pain and dyspnea were found in 100 and $60 \%$ of patients, respectively. An inlet port was found in 96\%. The topography of the inlet orifice was thoracic in 33 patients (66\%) and abdominal in 5 patients (10\%). One outlet was found in 11 cases (22\%) of which 3 were abdominal. A fluid and mixed pleural effusion syndrome was found in 22 and 13 patients, respectively. Anemia was found in 16 patients. The thoracic X-ray was performed in all patients and the lesions identified were listed in the Table 2. It was associated with an unprepared X-ray of the abdomen in 12 patients. Thoracoabdominal CT scan was performed in 14 patients. The lesions identified were listed in the Table 3. Thoracic wound was penetrating in 40 patients (80\%). Therapeutically, 26 patients received prehospital care. It consisted of dressing and compression bandage of haemorrhagic lesions. None of these patients had a venous route. Resuscitation including vascular filling (colloids and crystalloids) was performed in the 21 patients who had hemodynamic instability at admission. Eighteen (18) of

Table 2. Summary table of lesions on thoracic radiography.

\begin{tabular}{cc}
\hline Thoracic lesions & Number $(n=44)$ \\
Haemothorax & 23 \\
Haemopneumothorax & 13 \\
Coast fracture & 4 \\
Sternum fracture & 1 \\
Dorsal vertebra fracture & 2 \\
Clavicle fracture & 1 \\
\hline
\end{tabular}

Table 3. Summary table of the lesions on thoracoabdominal CT scan.

\begin{tabular}{cc}
\hline Lésions associées & Number $(n=14)$ \\
Haemothorax & 3 \\
Haemopneumothorax & 1 \\
Clavicle fracture & 1 \\
Perforation of an intra-abdominal hollow organ & 4 \\
Hepatic lesions & 2 \\
Dental avulsion & 1 \\
Hound of the artery under the right & 1 \\
Herfoperitoneum & 5 \\
Spleniclesion & 8 \\
\hline
\end{tabular}


these patients received a blood transfusion based on red blood cell concentrates and one patient benefited in addition to a transfusion of platelet concentrate. Oxygen therapy was performed in eight patients (16\%). Analgesia based on the combination of paracetamol and injectable nefopam was performed in $47 \mathrm{pa}$ tients $(94 \%)$. Serotonin and anti-tetanus toxoid therapy were systematically performed in 42 patients (84\%). A healing antibiotic treatment based on 3rd generation cephalosporin and imidazole was systematic in all our patients. A surgical indication was given in 39 patients (78\%). An isolated dressing was performed in 11 patients. The mean time between the accident and the surgery was 10.7 hours with extremes ranging from one hour to 30 hours. The average duration between admission to surgical emergencies and surgical procedure was 5.5 hours with extremes of one to 24 hours. The various surgical procedures performed have been summarized in Table 4. The average amount of blood drained was 744.4 $\mathrm{ml}$ with extremes of 300 to $1500 \mathrm{ml}$. Respiratory physiotherapy was performed in 39 patients. Hemodynamic instability was observed in 6 patients, pyothorax $(n=1)$, recurrence of haemothorax $(n=1)$ and pneumothorax $(n=1)$, and parietal suppuration $(n=1)$. These various complications have benefited from successful management. One patient was lost to follow-up and 7 patients (14\%) died. The mean hospital stay was 7.5 days with extremes of 1 to 35 days. Patients were reviewed in consultation 1 month then 3 months. Examination was normal.

\section{Discussion}

Thoracic wounds by firearm are frequent in Burkina Faso, as evidenced by the frequency of $27.3 \%$ of chest wounds at the university hospital YO over a period of 5 years. DeLesquen et al. in Afghanistan, have found 9.6\% of thoracic lesions among war casualties [5]. Debien and Lenoir in France in civilian practice found a prevalence of $19 \%$ [3]. The high incidence of thoracic gun injuries in our context as well as in developing countries is partly due to crime promoted by poverty and proliferation of weapons. The protections carried by the belligerents in a war zone expose the thorax less. The average age of our patients was approximately equal to that of De Lesquen et al. [5] and Randriamananjara et al. [6], who were respectively at an average age of 27.9 and 27 years. Two-thirds of our patients came from urban areas. This could be explained, on the one hand, by the repression of social manifestations; and on the other hand by unemployment and delinquency which favor armed attacks in cities. The control and regulation of the wearing of firearms in civilian practice could reduce the frequency of

Table 4. Summary of surgical gestures.

\begin{tabular}{cc}
\hline Surgical gestures & Number $(n=39)$ \\
\hline Thoracic drainage and trimming & 16 \\
Thoracotomy of clot removal & 2 \\
Laparotomy (digestive suture) and thoracic drainage & 8 \\
Isolated trim & 13 \\
\hline
\end{tabular}


armed attacks. Our patients consulted in the emergencies in less than 6 hours in $78 \%$ of the cases against an average duration of 4 days in Ayegnon et al. in Ivory Coast [7]. This is due to the effectiveness of sanitary evacuation structures and solidarity during events. However, medicalization of ambulances could make it possible to optimize pre-hospital management and improve the prognosis of patients. In our study as in that of Adegboye and al. [2] projectile weapons were the most used, contrary to a war zone where explosives predominated [8]. The patients in our series showed haemodynamic shock in $36 \%$ patients, compared with 49.6\% and 46\%, respectively, in Randriamananjara et al. [6] and Ayegnon et al. [7]. The high number of patients received in the first 6 hours in surgical emergencies in our study was a determining factor in hemodynamic stabilization. In our study as in that of several authors haemothorax and haemopneumothorax were the predominant diagnoses [2] [7] [9]. Radiography of the thorax is the first-line radiological examination easy to access. It makes it possible to make an initial lesional assessment, to look for possible associated lesions and to orient the management [10] [11]. It was carried out in all our patients and allowed the decision-making therapeutic in $78 \%$. The thoracoabdominal CT scan allows to fill the gaps in the $\mathrm{x}$-ray, to map the thoracic lesions and to look for the associated lesions [11]. Several associated lesions have been found in our study as in several authors and are important morbidity and mortality factors [3] [4] [7]. They must be vigorously researched and treated early. From a therapeutic point of view, resuscitation including blood transfusion was performed in $36 \%$ of our patients. It allowed the hemodynamic stabilization of our patients. In our study, as in several other authors, thoracic drainage constituted the main part of the surgical treatment [2] [12]. The cases of emergency invasive surgery were more concerned with the management of the associated lesions. This has been the case with us as well as with Ayegnon et al. [7]. We recorded a death rate of $14 \%$ against 23\% in Ayegnon et al. [7]. In war zones Debien and Lenoir [3] found a mortality rate attributable to the thoracic wound in $24 \%$. De Lesquen et al. [5] found an overall mortality of $11.2 \%$ during wartime in Afghanistan. These rates of death in civilian practice could be improved by strengthening the technical set-up both for the pre-hospital and hospital care of patients.

\section{Conclusion}

Thoracic wounds by firearm are a frequent reason for consultation in the visceral emergencies of the university hospital Yalgado Ouedraogo. Young adult males were the most affected. Physical assault was the more frequent circumstance and the pistol was the more involved weapon. The clinical picture of pleural effusion was found in the majority of patients. The thoracic radiograph and the CT scan were used to confirm the diagnosis and to investigate the associated lesions. Thoracic drainage was the most used surgical procedure. Mortality was heavy. The availability of medical transport and the optimization of management could greatly improve the prognosis of the thorax wounds by guns. Regulating the wearing of firearms would reduce the incidence of these lesions 


\section{Conflicts of Interest}

The authors declare no conflicts of interest related to this article.

\section{References}

[1] Berg, R.J., Inaba, K., Okoye, O., Karamanos, E., Strumwasser, A., Chouliaras, K., et al. (2014) The Peril of Thoracoabdominal Firearm Trauma: 984 Civilian Injuries Reviewed. The Journal of Trauma and Acute Care Surgery, 77, 684-691. https://doi.org/10.1097/TA.0000000000000436

[2] Adegboye, V.O., Ladipo, J.K., Brimmo, I.A. and Adebo, A.O. (2001) Penetrating Chest Injuries in Civilian Practice. African Journal of Medicine and Medical Sciences, 30, 327-331.

[3] Debien, B. and Lenoir, B. (2004) Traumatismes balistiques du thorax. Conférences d'actualisation. Congrès national d'anesthésie et de réanimation, Elsevier, Paris

[4] Hakimoglu, S., Karcioglu, M., Tuzcu, K., Davarcı, I., Koyuncu, O., Dikey, İ., et al. (2015) Assessment of the Perioperative Period in Civilians Injured in the Syrian Civil War. Rev. Bras. Anestesiol., 65, 445-449. https://doi.org/10.1016/j.bjan.2014.03.003

[5] de Lesquen, H., Béranger, F., Berbis, J., Ford, R.M., Bonnet, P.M., Thomas, P.A., et al. (2015) Traumatismes thoraciques de guerre en Afghanistan: analyse du registre du service de santé des armées français. e-mémoire de 1 Academie Nationale de Chirurgie, 14, 70-76.

[6] Randriamananjara, N., Ratovoson, H. and Ranaivozanany, A. (2001) Plaies penetrantes du thorax: bilan de notre prise en charge en urgence a propos de 151 observations colligées dans le service de chirurgie générale et thoracique du chu ampefiloha (Madagascar). Médecine d'Afrique Noire, 48, 270-273.

[7] Ayegnon, K.G., Lebeau, R., Amani, K.A.H., Menéas, C., Abro, S., Diby, F., et al. (2015) Aspects lésionnels et thérapeutiques des traumatismes thoraciques balistiques dans une population civile: à propos de 26 cas. Revue Africaine de Chirurgie et Spécialités, 9, 5-10.

[8] Pasquier, P., de Rudnicki, S., Donat, N., Auroy, Y. and Merat, S. (2011) Type et épidémiologie des blessures de guerre, à propos de deux conflits actuels: Irak et Afghanistan. Annales Francaises d'Anesthesie et de Reanimation, 30, 819-827. https://doi.org/10.1016/j.annfar.2011.05.018

[9] Mokrani, M., Metref, H., Harbi, F., Saidj, T. and Cherf, L. (2009) Traumatisme balistique thoracique: Expérience de la réanimation chirurgicale de l'hôpital central de l'armée algérienne. Retour sur 14 années d'activités. Revue Internationale des Services de Santé des Forces Armées, 82, 2.

[10] Duhamel, P., Bonnet, P.M., Pons, F., Jourdan, P. and Jancovici, R. (2003) Traumatismes balistiques du thorax. Agents vulnérants et balistique lésionnelle. Annales de Chirurgie Plastique Esthétique, 48, 128-134. https://doi.org/10.1016/S0294-1260(03)00015-3

[11] Clapson, P., Pasquier, P., Perez, J.-P. and Debien, B. (2010) Lésions pulmonaires liées aux explosions. Revue de Pneumologie Clinique, 66, 245-253. https://doi.org/10.1016/j.pneumo.2010.07.008

[12] Boyay, F. and Bellemare, P. (2004) Traumatismes et plaies thoraciques. Kinéréa., 39, $10-16$. 
Submit or recommend next manuscript to SCIRP and we will provide best service for you:

Accepting pre-submission inquiries through Email, Facebook, LinkedIn, Twitter, etc. A wide selection of journals (inclusive of 9 subjects, more than 200 journals)

Providing 24-hour high-quality service

User-friendly online submission system

Fair and swift peer-review system

Efficient typesetting and proofreading procedure

Display of the result of downloads and visits, as well as the number of cited articles Maximum dissemination of your research work

Submit your manuscript at: http://papersubmission.scirp.org/

Or contact ojts@scirp.org 